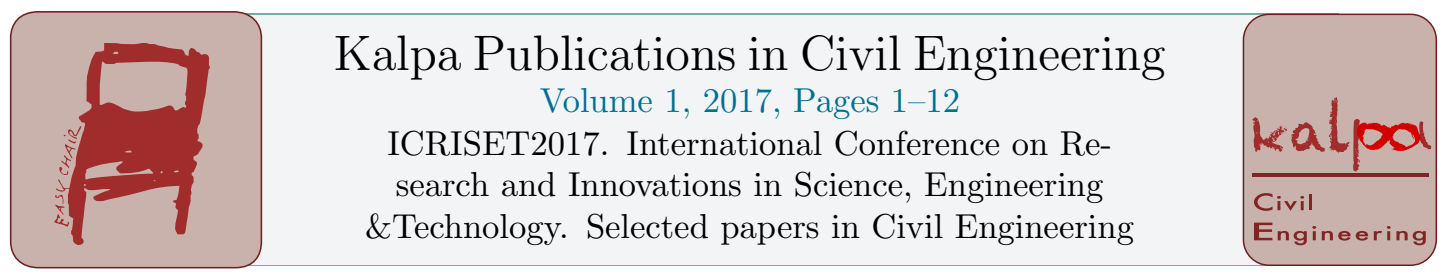

\title{
Progressive Collapse Assessment Of Reinforced Concrete Frame Structure With And Without Considering Actual Soil Condition
}

\author{
Bhavik R. Patel ${ }^{1}$ and Dr. Bharat J. Shah ${ }^{2}$ \\ ${ }^{1}$ (Research Scholar, GTU) \\ Civil Engineering Department \\ Silver Oak College of Engineering \& Technology \\ Ahmedabad, India \\ srsstructuralconsultants@gmail.com \\ ${ }^{2}$ (Professor \& Ph.D. Supervisor) \\ Applied Mechanics Department \\ Government Engineering College Modasa \\ Modasa, India \\ bjshah.ldce@gmail.com
}

\begin{abstract}
It has been found that the forces in the members of frame structures considering soil-structure interaction, differs than conventional method of analysis. Analysis considering soil-structure interaction is time-consuming process; hence, if the relation between two methods established, then by using conventional method, realistic results can be obtained. In the present work, effort has been made to study the impact of soil-structure interaction on the progressive collapse assessment of reinforced concrete frame structure (building). It is clear that the differential settlement of the foundation changes the load transfer system of the super structure. Differential settlement depends on the properties of the soil below foundation and the stiffness of the super structure. The objective of this study is to quantify the change in the reaction at the foundation level due to soil structure interaction. To achieve this target, the Winkler approach is used. In this model, soil below foundation is modelled as idealized springs. To study the effect of failure of load carrying elements i.e. columns on the entire structure; 15 storey moment resistant RC buildings is considered. The building is modelled and analyzed for progressive collapse using the structural analysis and design software SAP2000. Nonlinear static analysis is performed to understand the progressive collapse phenomena. The nonlinear static analysis is found to be the most efficient method for progressive collapse assessment of the reinforced concrete structure with consideration of soil effect. General Service Administration (GSA 2003) guideline is used for loading and procedure to assess the potential towards progressive collapse of structure.
\end{abstract}

C.D. Modhera, G.J. Joshi, D. Soni, I.N. Patel, A.K. Verma, L.B. Zala, S.D. Dhiman, D.R. Bhatt, J.M. Rathod, B.C. Goradiya, M.S. Holia and D.K. Patel (eds.), ICRISET2017 (Kalpa Publications in Civil Engineering, vol. 1), pp. 1-12 


\section{Introduction}

It has been observed that the forces estimated in the members of the frame structure are different from the conventional method of analysis, if soil-structure interaction is considered. As soil interaction is a very complex issue, the present study is based on following considerations. 1) Three different soil data are taken based on the past worked projects and the average value of SBC is taken for iteration 2) The footing of the columns is considered as isolated spread footings. 3) The settlement occurs due to normal consolidation of clay layer. 4) The distribution of contact pressure is assumed to be uniform. 5) The depth of foundation is assumed to be same for all footing. 6) Overlapping of pressure bulb is not considered. All three soil data are taken from the existing projects in Ahmedabad. Data was selected in such a way that the whole range of the clay soil exist in the Ahmedabad region will be covered. Selected soil properties are as follows:

Table 1-Selected soil properties of Soil

\begin{tabular}{|c|c|c|c|c|c|}
\hline Description & Symbol & $\begin{array}{c}\text { Firm clay } \\
\text { soil }\end{array}$ & $\begin{array}{c}\text { Very stiff } \\
\text { clay soil }\end{array}$ & $\begin{array}{c}\text { Hard clay } \\
\text { soil }\end{array}$ & Units \\
\hline N-value & $\mathrm{N}$ & 6 & 20 & 32 & - \\
\hline Field density & Y & 0.00172 & 0.00184 & 0.00198 & $\mathrm{~kg} / \mathrm{cm}^{3}$ \\
\hline $\begin{array}{c}\text { Natural water } \\
\text { content }\end{array}$ & $\mathrm{W}$ & 37.11 & 26.18 & 19.81 & $\%$ \\
\hline Cohesion & $\mathrm{C}$ & 0.15 & 0.8 & 1.1 & $\mathrm{~kg} / \mathrm{cm}^{2}$ \\
\hline $\begin{array}{c}\text { Unconfined } \\
\text { compressive } \\
\text { strength }\end{array}$ & $\mathrm{Q}$ & 0.22 & 1.3 & 2 & $\mathrm{~kg} / \mathrm{cm}^{2}$ \\
\hline $\begin{array}{c}\text { Specific } \\
\text { gravity }\end{array}$ & $\mathrm{G}$ & 2.67 & 2.69 & 2.7 & - \\
\hline $\begin{array}{c}\text { Compression } \\
\text { Index }\end{array}$ & $\mathrm{Cc}$ & 0.44 & 0.19 & 0.15 & - \\
\hline $\begin{array}{c}\text { Pre- } \\
\text { consolidation } \\
\text { pressure }\end{array}$ & $\mathrm{Pc}$ & 1.5 & 2.05 & 2.2 & $\mathrm{~kg} / \mathrm{cm}^{2}$ \\
\hline Gravel & & 0 & 7 & 0 & $\%$ \\
\hline Sand & & 6 & 11 & 16 & $\%$ \\
\hline Silt/Clay & & 94 & 82 & 84 & $\%$ \\
\hline Liquid Limit & $\mathrm{WL}$ & 75 & 59 & 64 & $\%$ \\
\hline $\begin{array}{c}\text { Plastic limit } \\
\text { Angle of shear } \\
\text { resistance }\end{array}$ & $\mathrm{PL}$ & 30 & 22 & 21 & $\%$ \\
\hline & 0 & 0 & 0 & 0 & $\mathrm{deg}$ \\
\hline
\end{tabular}

\section{About GSA guideline}

The General Service Administration Guideline was developed to assess the Progressive Collapse Analysis and Design for federal buildings by U.S. The purpose of these Guidelines is to: 1) Assist in the reduction of the potential for progressive collapse in new Federal Office Buildings 2) Assist in the 
assessment of the potential for progressive collapse in existing Federal Office Buildings 3) Assist in the development of potential upgrades to facilities if required. The guidelines provide the independent methodology to minimizing the potential for progressive collapse in the design of building structure. The guideline not includes the explicit part of a blast design/analysis. These Guidelines address the need to protect human life and prevent injury as well as the protection of Federal buildings, functions and assets. The Guidelines take a flexible and realistic approach to the reliability and safety of Federal buildings.

\section{Procedure To Find Out The Variation In Load Distribution And Simulate It For Progressive Collapse}

The step wise procedure to be followed

1) Calculate safe bearing capacity for the given soil data.

2) Analyze structure with conventional method. (Fixed Support Condition)

3) Design footing size for all columns and Find out the total settlement of all columns.

4) Find out spring constants for all columns.

5) Analyze structure with springs as supports.

6) Adopt new reactions and find out new spring constants for next iteration

7) Repeat the iterations till the difference of reaction of two subsequent iterations are found within the specified accuracy.

8) Apply final corrected reactions to all the columns.

9) Perform the NLS analysis for all four column removal cases.

10) Compare the result based on plastic hinge formation and percentage of load attempt by structure.

Step 1: Calculate Safe Bearing Capacity for given soil data

In this section the calculation has been done to find the safe bearing capacity of very stiff clay as per specified in Table 1. These properties are based on experiments carried out in the laboratory. However, experimental tests are not included in the scope of work. Assumptions for calculating the SBC are 1) Depth of Foundation (Df) $=2 \mathrm{~m}$ and 2) Width of Footing $(B)=2 \mathrm{~m}$. The value of SBC obtains using IS 6403:1981 and IS 8009:1976 is $250 \mathrm{kN} / \mathrm{m}^{2}$

Step 2: Analyze structure with conventional method for gravity and Seismic loading

Considering fixed supports condition and load combinations as per IS:456, base shear and reations at supports are determined. 
Step 3: Design footing size for all columns and Find out the total settlement of all columns.

The size of foundation and its settlement is determined using IS 6403 and IS 8009 respectively.

Step 4: Find out spring constants for all columns.

Sample calculation for the column shown as below.

$\mathrm{K}_{1,1}=\mathrm{Ro} 1 / \mathrm{y}$

$\mathrm{K}_{1,1}=3520.36 /(5.84 / 100)$

$\mathrm{K}_{1,1}=60280.14 \mathrm{kN} / \mathrm{m}$

Where Ro $=$ Unfactored load on column

$\mathrm{y}=$ Settlement of foundation

$\mathrm{K}_{1,1}=$ Spring stiffness for 1 st Iteration

Step 5: Analyze structure with springs as supports

After calculating "Equivalent Stiffness of Spring" for all columns these springs were attached to the column as a support. The snap shot (fig.1) shows the modelling scenario. After preparing new model with same configuration and spring supports, analysis was done. This analysis was considered as $1^{\text {st }}$ iteration. The table 2 shows support reaction after $1^{\text {st }}$ iteration for given structural system.
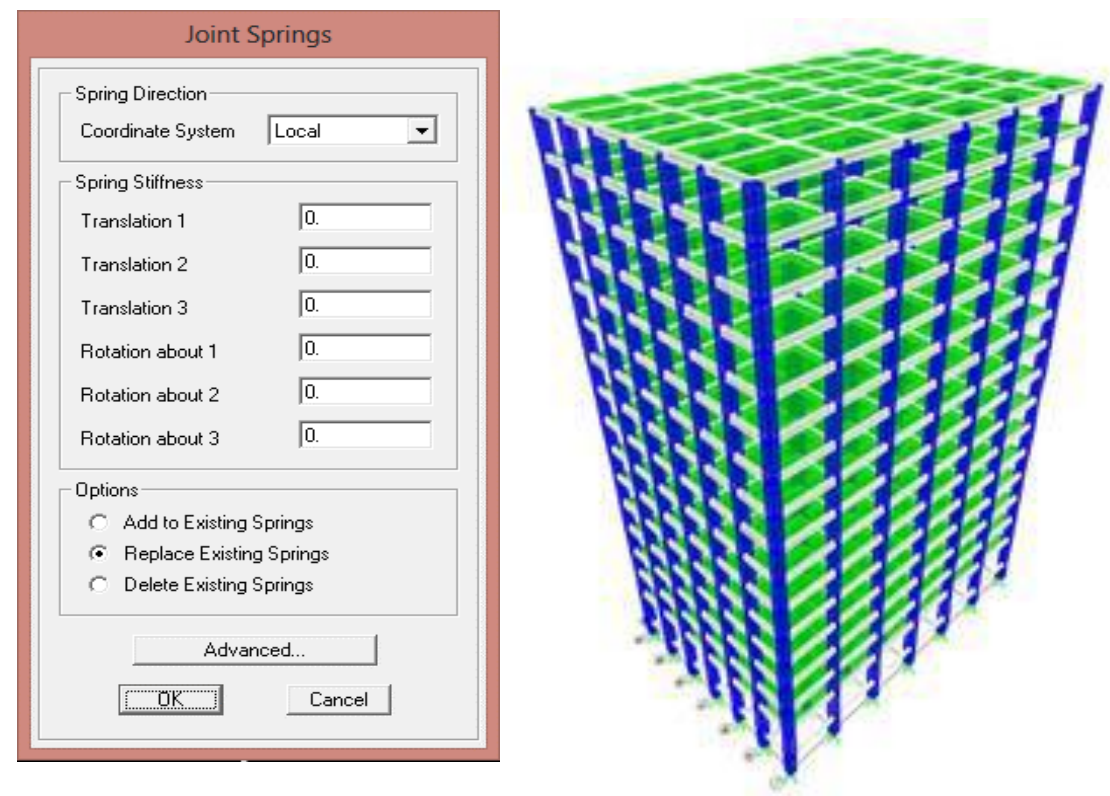

Figure 1 - Spring as Supports 
Table 2 - Support Reaction after $1^{\text {st }}$ Iteration

\begin{tabular}{|c|c|c|c|c|c|}
\hline $\begin{array}{c}\text { Column } \\
\text { No. }\end{array}$ & $\begin{array}{c}\text { Reactions } \\
\mathrm{kN}\end{array}$ & $\begin{array}{c}\text { Column } \\
\text { No. }\end{array}$ & $\begin{array}{c}\text { Reactions } \\
\mathrm{kN}\end{array}$ & Column No. & $\begin{array}{c}\text { Reactions } \\
\mathrm{kN}\end{array}$ \\
\hline 835 & 4053.92 & 852 & 5985.29 & 869 & 4628.07 \\
836 & 4952.59 & 853 & 5941.10 & 870 & 4498.58 \\
837 & 5143.24 & 854 & 5722.27 & 871 & 5553.56 \\
838 & 5182.79 & 855 & 4627.64 & 872 & 5762.63 \\
839 & 5143.24 & 856 & 4658.58 & 873 & 5805.30 \\
840 & 4952.59 & 857 & 5761.70 & 874 & 5762.63 \\
841 & 4053.92 & 858 & 5983.24 & 875 & 5553.56 \\
842 & 4497.60 & 859 & 6027.88 & 876 & 4498.58 \\
843 & 5552.87 & 860 & 5983.24 & 877 & 4049.82 \\
844 & 5762.12 & 861 & 5761.70 & 878 & 4953.62 \\
845 & 5804.84 & 862 & 4658.58 & 879 & 5144.01 \\
846 & 5762.12 & 863 & 4628.07 & 880 & 5183.50 \\
847 & 5552.87 & 864 & 5722.60 & 881 & 5144.01 \\
848 & 4497.60 & 865 & 5941.34 & 882 & 4953.62 \\
849 & 4627.64 & 866 & 5985.50 & 883 & 4049.82 \\
850 & 5722.27 & 867 & 5941.34 & & \\
851 & 5941.10 & 868 & 5722.60 & & \\
\hline
\end{tabular}

Step 6: Adopt new reactions and find out new spring constants for next iteration

Now onwards for all the iterations the value of "Equivalent Stiffness of the Spring" should be calculated from the Winkler's formula given below.

$$
K_{k, i}=\left[\frac{R_{k-1, i}-R_{k-2, i}}{2 R_{0, i}}+1\right] K_{k-1, i}
$$

$\mathrm{K}_{\mathrm{k}, \mathrm{i}}=$ Equivalent Spring attached to the ith support at $\mathrm{k}^{\mathrm{th}}$ iteration

$\mathrm{k}=$ Number of iteration

$\mathrm{R}_{\mathrm{k}, \mathrm{i}}=$ The reaction at support at the $\mathrm{k}^{\text {th }}$ iteration

$\mathrm{R}_{0, \mathrm{i}}=$ Reaction at the $\mathrm{i}^{\text {th }}$ support at Zero iteration

The value of " $k$ " will increase with the increment of the number of iteration. For the third iteration the $\mathrm{k}$ equal to 3 and for forth iteration $\mathrm{k}$ equal to 4 . Table 3 shows the equivalent stiffness of springs for second iteration. 
Profressive Collapse Assessent ...

Bhavik Patel and Bharat Shah

Table 3 - Equivalent Stiffness of springs for $2^{\text {nd }}$ Iteration

\begin{tabular}{|c|c|c|c|c|c|}
\hline $\begin{array}{c}\text { Column } \\
\text { No. }\end{array}$ & $\begin{array}{c}\text { Spring For 2 } \\
\text { iteration } \\
\mathrm{kN} / \mathrm{m}\end{array}$ & $\begin{array}{c}\text { Column } \\
\text { No. }\end{array}$ & $\begin{array}{c}\text { Spring For 2 } \\
\text { iteration } \\
\mathrm{kN} / \mathrm{m}\end{array}$ & $\begin{array}{c}\text { Column }^{\text {No. }} \\
\text { No. }\end{array}$ & $\begin{array}{c}\text { Spring For 2 } \\
\text { iteration } \\
\mathrm{kN} / \mathrm{m}\end{array}$ \\
\hline 835 & 64848.28 & 852 & 78497.00 & 869 & 69034.10 \\
836 & 71399.40 & 853 & 78210.41 & 870 & 68072.90 \\
837 & 72764.29 & 854 & 76763.11 & 871 & 75614.34 \\
838 & 73046.72 & 855 & 69030.86 & 872 & 77019.28 \\
839 & 72764.29 & 856 & 69260.17 & 873 & 77301.06 \\
840 & 71399.40 & 857 & 77027.68 & 874 & 77019.28 \\
841 & 64749.53 & 858 & 78487.77 & 875 & 75614.34 \\
842 & 68065.26 & 859 & 78776.22 & 876 & 68072.90 \\
843 & 75609.78 & 860 & 78487.77 & 877 & 64714.45 \\
844 & 77015.98 & 861 & 77027.68 & 878 & 71406.89 \\
845 & 77298.07 & 862 & 69260.17 & 879 & 72769.81 \\
846 & 77015.98 & 863 & 69034.10 & 880 & 73051.81 \\
847 & 75609.78 & 864 & 76765.24 & 881 & 72769.81 \\
848 & 68065.26 & 865 & 78211.96 & 882 & 71406.89 \\
849 & 69030.86 & 866 & 78498.39 & 883 & 64714.45 \\
850 & 76763.11 & 867 & 78211.96 & & \\
851 & 78210.41 & 868 & 76765.24 & & \\
\hline
\end{tabular}

Step 7: Repeat the iterations till the difference of reaction of two subsequent iterations are found within the specified accuracy

Table - 4 Support Reactions after Iterations

\begin{tabular}{|c|c|c|c|c|c|c|c|}
\hline Column No. & $\begin{array}{c}5^{\text {th }} \text { Iteration } \\
\mathrm{kN}\end{array}$ & $\begin{array}{c}6^{\text {th }} \text { Iteration } \\
\mathrm{kN}\end{array}$ & $\begin{array}{c}7^{\text {th }} \text { Iteration } \\
\mathrm{kN}\end{array}$ & $\begin{array}{c}8^{\text {th }} \text { Iteration } \\
\mathrm{kN}\end{array}$ & $\begin{array}{c}9^{\text {th }} \text { Iteration } \\
\mathrm{kN}\end{array}$ & $\begin{array}{c}10^{\text {th }} \text { Iteration } \\
\mathrm{kN}\end{array}$ & $\begin{array}{c}11^{\text {th }} \text { Iteration } \\
\mathrm{kN}\end{array}$ \\
\hline 835 & 4372.78 & 4376.75 & 4378.28 & 4378.88 & 4379.11 & 4379.21 & 4379.24 \\
\hline 836 & 5030.12 & 5031.13 & 5031.55 & 5031.72 & 5031.80 & 5031.83 & 5031.84 \\
\hline 837 & 5296.48 & 5299.29 & 5300.43 & 5300.89 & 5301.08 & 5301.16 & 5301.19 \\
\hline 838 & 5362.88 & 5366.00 & 5367.23 & 5367.71 & 5367.90 & 5367.97 & 5368.00 \\
\hline 839 & 5296.86 & 5299.68 & 5300.82 & 5301.28 & 5301.47 & 5301.55 & 5301.58 \\
\hline 840 & 5031.35 & 5032.40 & 5032.83 & 5033.01 & 5033.08 & 5033.12 & 5033.13 \\
\hline 841 & 4365.44 & 4369.28 & 4370.77 & 4371.34 & 4371.57 & 4371.66 & 4371.70 \\
\hline 842 & 4587.34 & 4586.91 & 4586.59 & 4586.41 & 4586.32 & 4586.27 & 4586.25 \\
\hline 843 & 5367.22 & 5363.84 & 5362.45 & 5361.87 & 5361.63 & 5361.53 & 5361.49 \\
\hline 844 & 5649.81 & 5648.15 & 5647.44 & 5647.13 & 5647.00 & 5646.94 & 5646.92 \\
\hline 845 & 5718.19 & 5716.78 & 5716.13 & 5715.83 & 5715.70 & 5715.64 & 5715.61 \\
\hline 846 & 5650.10 & 5648.44 & 5647.73 & 5647.43 & 5647.29 & 5647.24 & 5647.21 \\
\hline 847 & 5368.08 & 5364.72 & 5363.33 & 5362.76 & 5362.52 & 5362.42 & 5362.38 \\
\hline 848 & 4589.38 & 4589.01 & 4588.73 & 4588.56 & 4588.48 & 4588.43 & 4588.41 \\
\hline 849 & 4711.35 & 4711.79 & 4711.94 & 4712.00 & 4712.02 & 4712.03 & 4712.04 \\
\hline 850 & 5531.32 & 5528.97 & 5528.11 & 5527.80 & 5527.69 & 5527.65 & 5527.64 \\
\hline 851 & 5824.84 & 5824.24 & 5824.09 & 5824.06 & 5824.06 & 5824.06 & 5824.06 \\
\hline 852 & 5895.05 & 5894.72 & 5894.63 & 5894.61 & 5894.60 & 5894.60 & 5894.60 \\
\hline 853 & 5825.04 & 5824.45 & 5824.29 & 5824.26 & 5824.26 & 5824.26 & 5824.26 \\
\hline 854 & 5531.88 & 5529.53 & 5528.68 & 5528.37 & 5528.26 & 5528.22 & 5528.21 \\
\hline 855 & 4712.46 & 4712.92 & 4713.08 & 4713.14 & 4713.16 & 4713.17 & 4713.18 \\
\hline 856 & 4749.52 & 4750.40 & 4750.76 & 4750.91 & 4750.98 & 4751.01 & 4751.02 \\
\hline 857 & 5579.32 & 5577.45 & 5576.82 & 5576.61 & 5576.54 & 5576.52 & 5576.52 \\
\hline 858 & 5876.29 & 5876.19 & 5876.26 & 5876.33 & 5876.37 & 5876.39 & 5876.40 \\
\hline 859 & 5947.13 & 5947.29 & 5947.44 & 5947.52 & 5947.56 & 5947.57 & 5947.58 \\
\hline 860 & 5876.42 & 5876.32 & 5876.39 & 5876.46 & 5876.50 & 5876.52 & 5876.53 \\
\hline 861 & 5579.67 & 5577.80 & 5577.17 & 5576.96 & 5576.89 & 5576.87 & 5576.87 \\
\hline 862 & 4750.20 & 4751.08 & 4751.45 & 4751.60 & 4751.67 & 4751.70 & 4751.71 \\
\hline 863 & 4712.12 & 4712.57 & 4712.72 & 4712.78 & 4712.81 & 4712.82 & 4712.82 \\
\hline 864 & 5531.75 & 5529.40 & 5528.55 & 5528.24 & 5528.13 & 5528.09 & 5528.08 \\
\hline 865 & 5825.07 & 5824.47 & 5824.32 & 5824.28 & 5824.28 & 5824.28 & 5824.28 \\
\hline 866 & 5895.19 & 5894.85 & 5894.76 & 5894.74 & 5894.74 & 5894.74 & 5894.74 \\
\hline 867 & 5825.14 & 5824.54 & 5824.39 & 5824.36 & 5824.35 & 5824.36 & 5824.36 \\
\hline 868 & 5531.96 & 5529.61 & 5528.76 & 5528.45 & 5528.34 & 5528.30 & 5528.28 \\
\hline 869 & 4712.58 & 4713.03 & 4713.19 & 4713.25 & 4713.27 & 4713.28 & 4713.28 \\
\hline 870 & 4589.36 & 4588.96 & 4588.66 & 4588.49 & 4588.40 & 4588.35 & 4588.33 \\
\hline 871 & 5368.17 & 5364.80 & 5363.41 & 5362.84 & 5362.60 & 5362.50 & 5362.46 \\
\hline 872 & 5650.30 & 5648.64 & 5647.93 & 5647.62 & 5647.49 & 5647.43 & 5647.41 \\
\hline 873 & 5718.49 & 5717.08 & 5716.43 & 5716.14 & 5716.00 & 5715.94 & 5715.91 \\
\hline 874 & 5650.32 & 5648.66 & 5647.95 & 5647.64 & 5647.51 & 5647.45 & 5647.43 \\
\hline 875 & 5368.27 & 5364.90 & 5363.51 & 5362.93 & 5362.70 & 5362.60 & 5362.56 \\
\hline 876 & 4589.68 & 4589.28 & 4588.98 & 4588.80 & 4588.71 & 4588.67 & 4588.65 \\
\hline 877 & 4365.31 & 4369.22 & 4370.73 & 4371.32 & 4371.56 & 4371.65 & 4371.69 \\
\hline 878 & 5031.74 & 5032.77 & 5033.19 & 5033.37 & 5033.44 & 5033.48 & 5033.49 \\
\hline 879 & 5297.32 & 5300.14 & 5301.28 & 5301.74 & 5301.93 & 5302.00 & 5302.04 \\
\hline 880 & 5363.45 & 5366.57 & 5367.79 & 5368.27 & 5368.46 & 5368.54 & 5368.57 \\
\hline 881 & 5297.29 & 5300.10 & 5301.24 & 5301.70 & 5301.89 & 5301.97 & 5302.00 \\
\hline 882 & 5031.73 & 5032.75 & 5033.17 & 5033.35 & 5033.42 & 5033.45 & 5033.47 \\
\hline 883 & 4365.47 & 4369.39 & 4370.90 & 4371.49 & 4371.72 & 4371.81 & 4371.85 \\
\hline
\end{tabular}


Step 8: Apply final corrected reactions to all columns and calculate the percentage of GSA loading taken by the structure after soil-structure interaction.

\section{Step 9: Perform NLS analysis to specified column removal cases}

As per the GSA guidelines, four cases of column removal as shown in fig.-2, shall be considered for the progressive collapse assessment of the framed structure. Nonlinear static analysis is carried out using SAP2000 software. Fig.-3 shows the local damage scenario by removing the external corner column $\mathrm{C}-1 \mathrm{~A}$ and hinges developed during NLS analysis. GSA guideline prescribes loading as 2(DL+ $0.25 \mathrm{LL}$ ) on the structure. Load is incremented till the chord rotation of beam members at column removal place reached within 0.015 radian as per the failure criteria prescribed in ASCE 41 and FEMA 356. Accordingly, for the given problem, when displacement at the place of column removal reaches to $100 \mathrm{~mm}$ is taken as the failure condition.

Fig. 4, 5, 6, \& 7 shows the variation of $\%$ GSA load v/s displacement at the column removal place for four column removal cases respectively. Ultimate loads for NLS analysis considering fixed based and considering soil stiffness is also given below each figure.

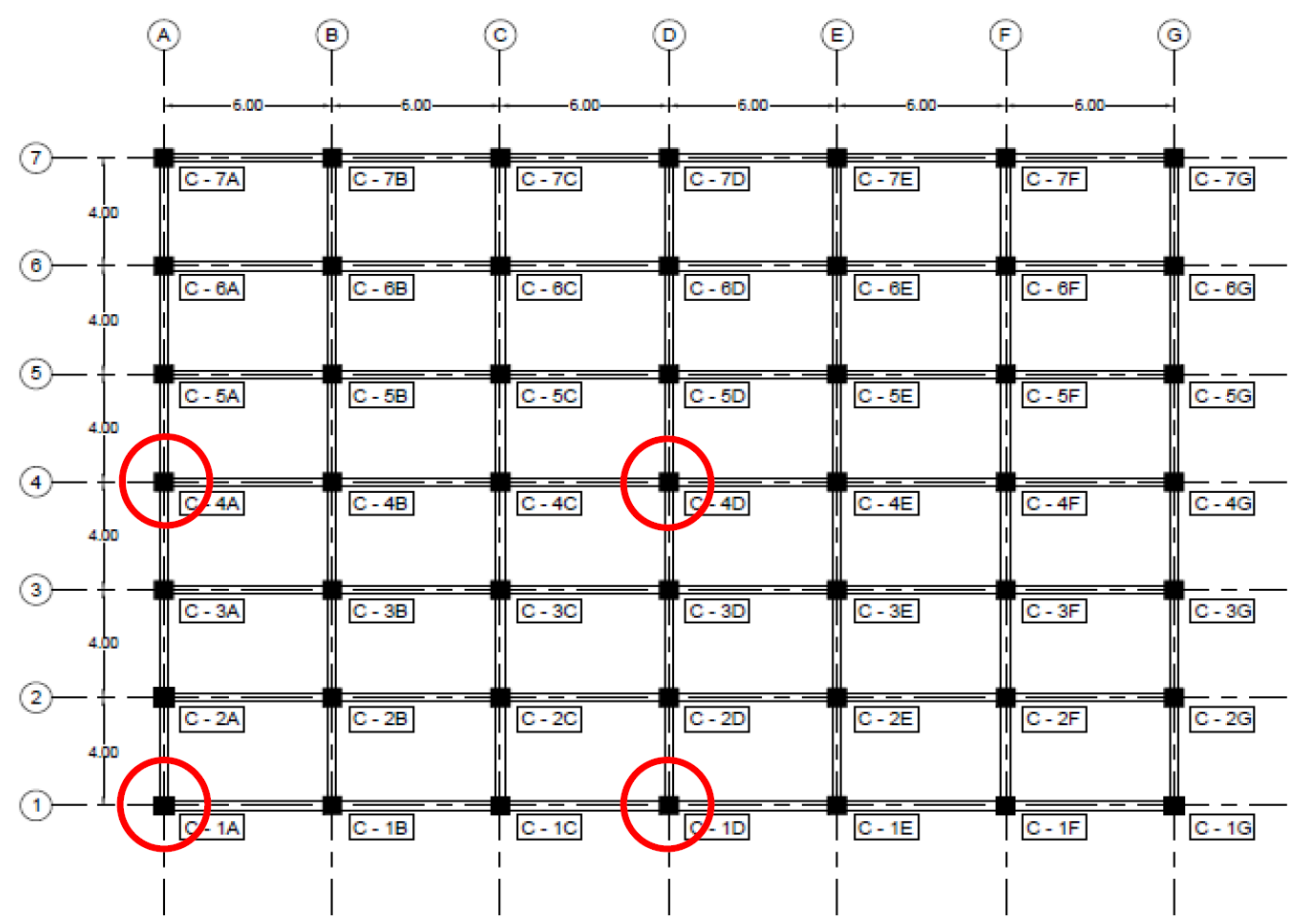

Figure 2 - Column removal location 

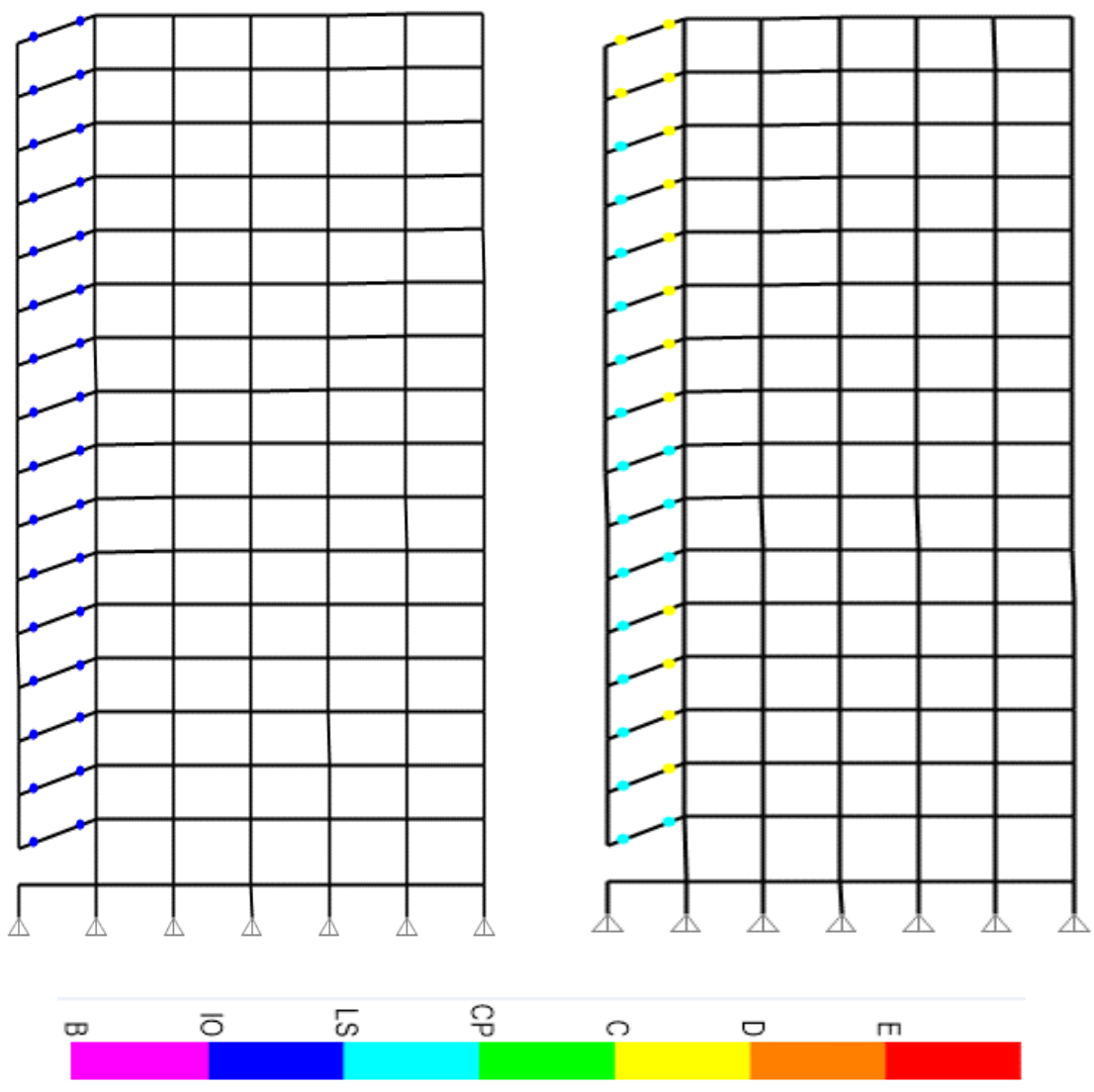

Figure 3 - Building frames with hinge formation along major and minor direction of building respectively at corner column removal

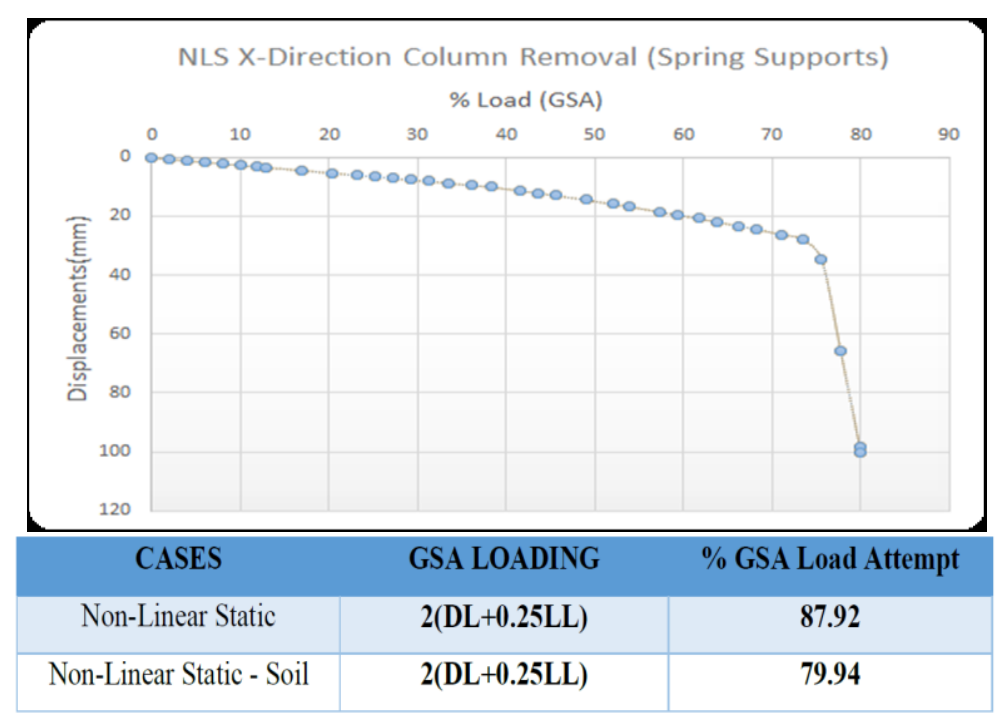

Figure 4 - \% load attempt for Case 1 Non-Linear Static Analysis (Soil) 


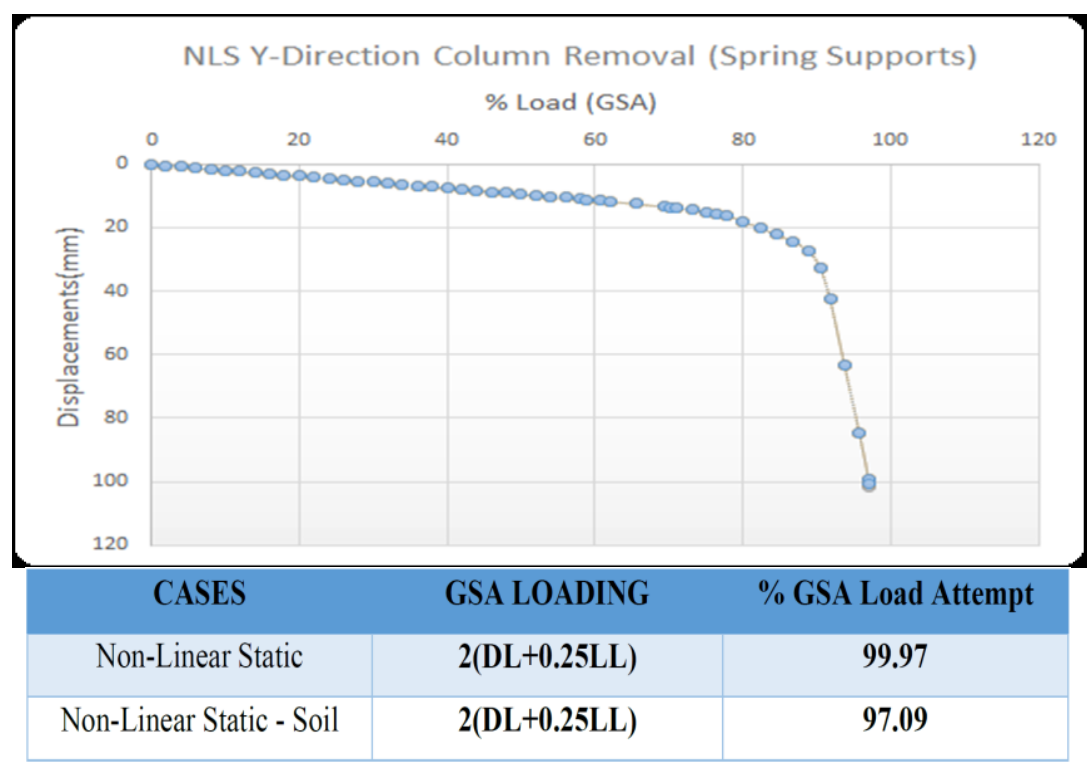

Figure 5 - \% load attempt for Case 2 Non-Linear Static Analysis (Soil)

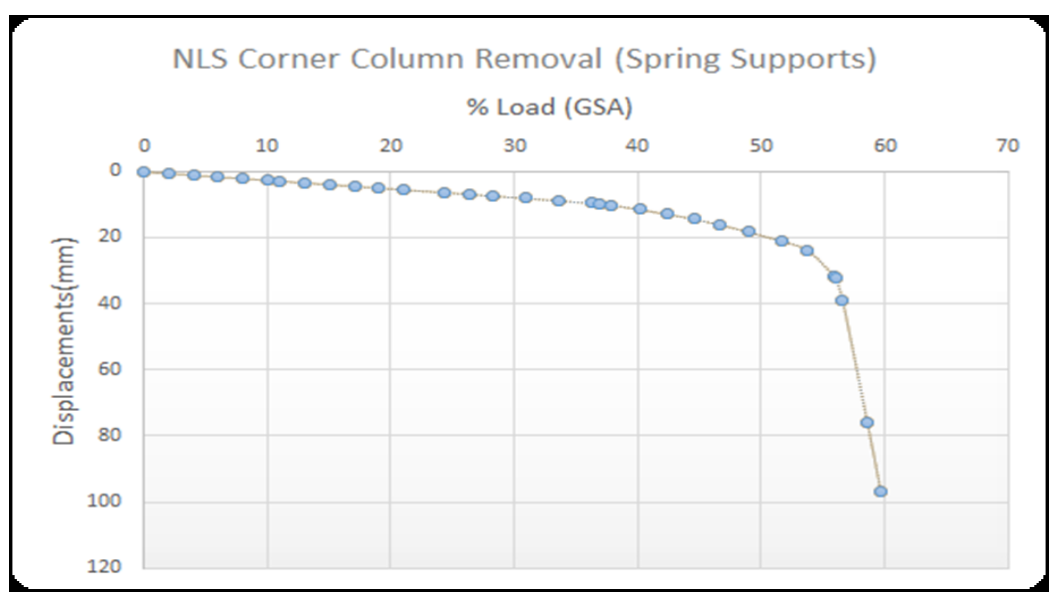

\begin{tabular}{|c|c|c|}
\hline CASES & GSA LOADING & \% GSA Load Attempt \\
\hline Non-Linear Static & 2(DL+0.25LL) & $\mathbf{7 8 . 2 6}$ \\
\hline Non-Linear Static - Soil & 2(DL+0.25LL) & $\mathbf{5 9 . 6 3}$ \\
\hline
\end{tabular}

Figure 6 - \% load attempt for Case 3 Non-Linear Static Analysis (Soil) 


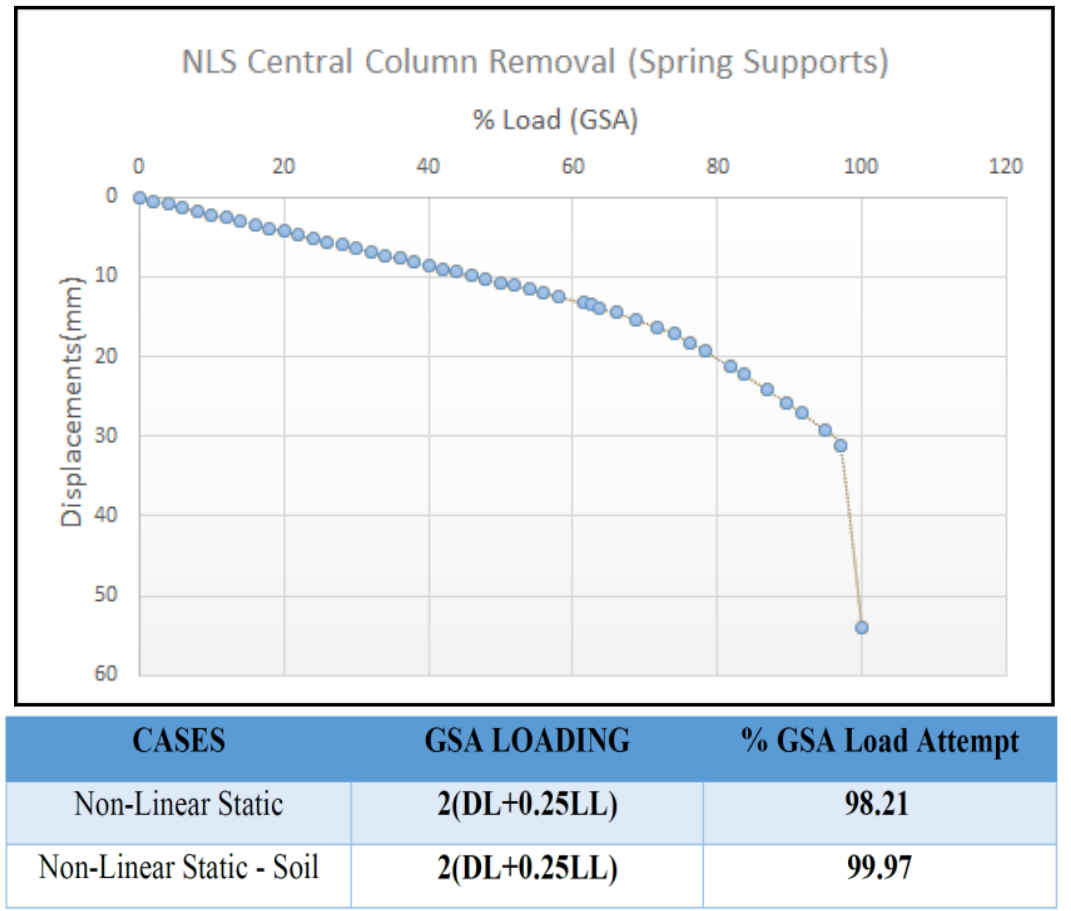

Figure 7 - \% load attempt for Case 4 Non-Linear Static Analysis (Soil)

\section{Results and Discussion}

In the present study, $\mathrm{G}+15$ storied $\mathrm{RC}$ framed structures is analyzed for progressive collapse assessment using GSA guideline. The effect of soil stiffness in the progressive collapse assessment is also shown in this paper. From the result, it can be seen that,

1. The ultimate load considering soil stiffness found lesser value than without soil stiffness in all four column removal cases except in central column removal case, there is marginally increase.

2. In the corner column removal case (Fig. 6), the ultimate load varies significantly with and without considering soil stiffness. i.e. $59.63 \%$ of GSA load with soil stiffness and $78.26 \%$ of GSA load without soil stiffness.

3. In the exterior bay column removal case (fig. $4 \& 5$ ), the ultimate load does not much vary. In the exterior bay column removal, the variation is little more in long exterior bay (fig. 4) than short exterior bay (fig. 5) column removal case.

4. The interior column removal case (fig. 7), the variation in the ultimate load with \& without soil stiffness is almost negligible.

In the progressive collapse analysis, considering soil stiffness may vary the results due to change in the soil stiffness after removal of column condition. The soil stiffness determined by achieving equilibrium of forces at foundation gets disturbed once column is removed from the structure at 
foundation level. But in the present study, this part is ignored and the same soil stiffness are taken before and after column removal condition.

\section{Conclusion}

Following conclusions can be drawn from the study of progressive collapse assessment of G+15storied RC framed structure with \& without effect of soil stiffness.

- The support reactions of the footing changes considerably considering fixed based support condition and soil structure interaction.

- The structure was checked for potential of progressive collapse using GSA guideline with \& without consideration of actual soil condition. The NLS analysis for all four cases of column removal prescribed in the GSA guideline shown that the ultimate load is lesser with consideration of soil stiffness than without soil stiffness case. That means that progressive collapse assessment of RC frames structure considering soil stiffness is more vulnerable than without soil stiffness case.

- For evaluating progressive collapse assessment, again corner column removal case gives worst effect. i.e. about $20 \%$ lesser value of ultimate load in the case of consideration of soil stiffness than not considering it.

In summary, the process of analysis using actual soil condition is time consuming and tedious, but the role of soil affects a lot in the behavior of progressive collapse of structure, so it is recommended that the role of soil should be considered in progressive collapse assessment of structure.

\section{References}

Sorensen A. and McGill W. L., "Utilization of Existing Blast Analysis Software Packages for the Back-Calculation of Blast Loads" DOI: 10.1061/(ASCE)CF.1943-5509.0000209. (C) 2012 American Society of Civil Engineers.

Spencer E. Quiel and Shalva M. Marjanishvili, "Fire Resistance of a Damaged Steel Building Frame Designed to Resist Progressive Collapse" 10.1061/(ASCE)CF.1943 5509.0000248. (C) 2012 Society of Civil Engineers.

Zhiwei Huang; Bing Li; and Piyali Sengupta, "Reliability Assessment of Damaged RC MomentResisting Frame against Progressive Collapse under Static Loading Conditions" 10.1061/(ASCE)EM.1943-7889.0000455. ( 2013 American Society of Civil Engineers. 
Aldo McKay, Kirk Marchand; and Manuel Diaz, "Alternate Path Method in Progressive Collapse Analysis: Variation of Dynamic and Nonlinear Load Increase Factors" 10.1061/(ASCE) SC.19435576.0000126. (C) 2012 American Society of Civil Engineers.

Cheol-Ho Lee; Seonwoong Kim; and Kyungkoo Lee, P.E, "Parallel Axial- Flexural Hinge Model for Nonlinear Dynamic Progressive Collapse Analysis of Welded Steel Moment Frames" 10.1061/ASCE ST.1943-541X.0000102 ( 2012 American Society of Civil Engineers.

Su, Y. P., Tian, Y., and Song, X. S. (2009). "Progressive collapse resistance of axially-restrained frame beams.” ACI Struct. J., 106(5), 600-607

Yap, S. L., and Li, B. (2011). "Experimental investigation of RC exterior beam-column subassemblages for progressive collapse." ACI Struct. J., 108(5), 542-552

General Services Administration (GSA). (2003). Progressive collapse analysis and design guidelines for new federal office buildings and major modernization projects, Washington, DC. 